\title{
水溶液中の不純物によるゲルマニウム およびシリコン表面の污染*
}

阿部敏雄 ${ }^{* *}$ 大井昇*** 飯田光雄 ${ }^{* *}$

Toshio Abe, Noboru Oi and Mitsuo Iida: Contamination of the Surface of Germanium and Silicon Caused by Impurities in Aqueous Solutions. Using the radioactive tracers, ${ }^{198} \mathrm{Au},{ }^{111 \mathrm{Ag}},{ }^{59} \mathrm{Fe}$, and ${ }^{64} \mathrm{Cu}$, experiments have been made to see how metallic impurities are absorbed on the surface of $\mathrm{Ge}, \mathrm{Si}, \mathrm{Mo}$, clear quartz, and polyethylene from several kinds of aqueous solution, and how the absorbed impurities are desorbed by acid etching or $\mathrm{NaCN}$ aq. treatment. Besides, using the resistivity change of Ge by heat treatment in clean atmosphere, $\mathrm{Cu}$ concentration absorbed on Ge surface from water under various conditions has been measured. The experimental results are as follows: (1) Over $1013 \mathrm{atoms} / \mathrm{cm}^{2}$ of the metallic elements are absorbed on $\mathrm{Ge}$ and $\mathrm{Si}$ surfaces by dipping the crystals into water containing $\mathrm{Au}^{+++}$, $\mathrm{Ag}^{+}$, or $\mathrm{Cu}++$ ion $\left(10^{14} \mathrm{ions} / \mathrm{c} . \mathrm{c}\right)$ for $30 \mathrm{~min}$. (2) $\mathrm{Fe}\left(\approx 10^{14} \mathrm{atoms} / \mathrm{c} . \mathrm{c}\right)$ in water is scarcely absorbed on any of the substances $\left(<10^{10}\right.$ atoms $\left./ \mathrm{cm}^{2}\right)$ for $30 \mathrm{~min}$ at $\mathrm{pH}=1$, but absorbed largely $\quad>10^{12}$ atoms $/ \mathrm{c}$.c) at $\mathrm{pH}=7$. (3) $\mathrm{Au}, \mathrm{Ag}\left(\approx 10^{14}\right.$ atoms/c.c) in $\mathrm{HF}+\mathrm{HNO}_{3}$, and $\mathrm{Au}\left(\approx 10^{14}\right.$ atoms/c.c), $\mathrm{Fe}$

**東宗芝浦電気株式会社,管球事業部 (Lamp and Tube Division, Tokyo Shibaura Electric Co., Ltd., Kanagawa)

*** 東京芝溥電気株式会社，中央研究所 (Central Re- search Laboratory, 'Tokyo Shibaura Electric Co., Ltd., Kawasaki)

* 1959 年 11 月本会大阪大会に一部発表 
$\left(\approx 1015\right.$ atoms/c.c) in $\mathrm{NaCN}$ aq. can be absorbed considerably $\left(1010 \sim 10^{13}\right.$ atoms $/ \mathrm{cm}^{2}$ for $\left.30 \mathrm{~min}\right)$ on Ge and Si surface. The degree of cleanness of the surface of $\mathrm{Ge}$, or $\mathrm{Si}$ as etched with acid, dipped in $\mathrm{NaCN}$ aq. and washed with pure water, is limited by the facts (1), (2), and (3).

(Received December 11, 1961)

\section{I. 緒 䇏}

ゲルマニウム, シリコンなど半導体材料を，高温度で熱 処琵すると，半尊体材料の電気的性質，すなわり此抵抗，伝 導型，少数キ+リアの素命などが著しく変化する(1)(2)(3)(4)。 そしてその原因の中で,不純物によるものとしては，熱処理 前半導体材料表面儿吸着されていた金属不純物，扣よび加

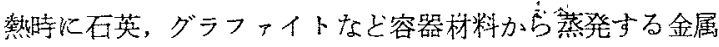
不純物が，熱処理時に半導体材料中に拡散侵入することが 最る重要な現象であることはよく知られてきた (3)(4)(5)。

本報告は材料としてはゲルマニウム，ショコン，执よび これらの半導体材料を取报 弓時，同時にひらく用いられる 石英，モリブデン，ポリェチレンを選び，これらの材料を 各種金属不純物を含も水溶液に浸漬した場合の吸着，およ び吸着された不純物の各種化学処理による脱着についての 実跧結果をなとめたわのである：

\section{II. 故射性同位元素を用いた寒験}

\section{1. 実、験方法}

用いた不純物は金、銀、鉄、銅で离る。198 $\mathrm{Au}, 111 \mathrm{Ag}$ ， 59Fe は Oak Ridge National Lab.から㣀入された。拉の 招のは $\mathrm{AuCl}_{3}$ の塩酸酸性溶液, $\mathrm{AgNO}_{3}$ の硝酸酸性溶液， $\mathrm{FeCl}_{3}$ の塩酸酸性浴液になつていた。なたおのおのの比放 射能は Au が $3.4 \times 10^{5} \sim 4.2 \times 10^{5} \mathrm{mc} / \mathrm{g}, \mathrm{Fe}$ は $6 \times 10^{3} \sim$ $1.53 \times 10^{4} \mathrm{mc} / \mathrm{g}, \mathrm{Ag}$ は無担体であった。これらの水溶液 を0.01 mLのミクロピペットで採取,水打よび各種水溶液 で稀釈する，この一定量 (1 c c 程度) の放射能を測定し，金 属原子当りの比放射能を決定した*．次に稀积された溶液 中心，適学に表面処理された幾何学的表面積 $2 \sim 100 . \mathrm{cm}^{2}$ の試料をある時間浸漬後, 㜔イオン水洗涹, 乾燥して湘定 にかけた，液の攪拌はかなり效果がるので，石英製のか ごに試料をのせて溶液中で半径約 $5 \mathrm{~cm}$ の円運動を行なつ た. 廻転数注約 3 r.p.m.である。また水洗特間に上つて は吸着量はほとんど変化しないことは尒め確めた。つぎに 試料の表面処理について記す. Ge,Si の試料好厚さ2 3 $\mathrm{mm}$ の薄片で表面は(111) 面である。この試料をあらかり゙ め $\mathrm{HNO}_{3}+\mathrm{HF}(1: 1)$ て酸食，水洗したものを実験に用い た。石英板は材質は透明石英ガラスであり，HFで酸食， 水洗したものを用いた，Mo板は $\mathrm{HCl}$ で酸食，水洗したる のを用いた。ポリエチレン板はトリクロルエチレンで脱脂

(1) H.Letaw: J.Phys. Chem. Solid, 1 (1956) , 100.

(2) G.Bemski and J.D.Struthers: J.Electrochem. Soc., $105(1958), 588$.

(3) H.C.Theuerer, J.M.Whelan, H.E.Bridgers and E.Buehler: J.Electrochem. Soc., $104(1957), 721$.

（4）加藤，阿部：東管レビェ一, 15(1960), 584 .

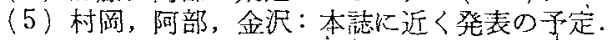

* 擃度の数値は R.I.についていた Specification の数 值を用いた。
嵝、アセトン，および純水で洗涤したものを用いた。

測定はウエルタイプのシンチレーションスペクトロメー タ $(1.5$ インチ $\phi$, ウェル0.6インチ $\phi)$ を用いて行なつた。

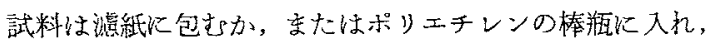
クリスタル中に置き測定した。前に述べた悇属愿子当りの 放射能々試片の湘定值を比輅することにより，陚片表面に 吸着されている金属状不純物の総量を求めることができ る。な虾比放射能加这算して Au， Ag, Fe の検出可能の 最低量の原子数は打のおの約 $10^{10}, 2 \times 10^{11}$, お゙よび $6 \times 10^{10}$ であつた。

、64Cu は高純度の金属銅 $(99.999 \%)$ ， JRR-1 実験孔，No. 16 (中性子束 $5 \times 1011 / \mathrm{cm}^{2}, \mathrm{sec}$ ) で 2 時間照射にて得た。試 料到着 (このときの比放射能は約 $200 \mathrm{mc} / \mathrm{g}$ ) 後直ちに $\mathrm{HNO}_{3}$ に溶解し、Auなどと同様に実験を行ならた。な和半減期 の湘定による ${ }^{64} \mathrm{Cu}$ の放射化学的純度は $99.9 \%$ 以上であっ

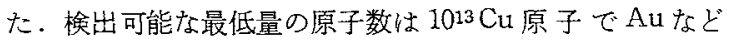
に比してかなり感度が低いので，水中 Cu濃度の低い場合

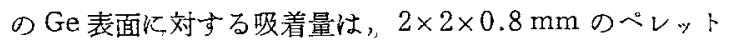
$10 \mathrm{~g}$ (約 $380 \mathrm{~cm}^{2}$ の表面積を持つ) を用いて表面積当りの感 度を上げて测定した。

\section{2. 実験 結 果}

Fig.1 は水中 $\mathrm{Au}, \mathrm{Ag}, \mathrm{Fe}, \mathrm{Cu}$ 濃度と，その中に 30 分閭

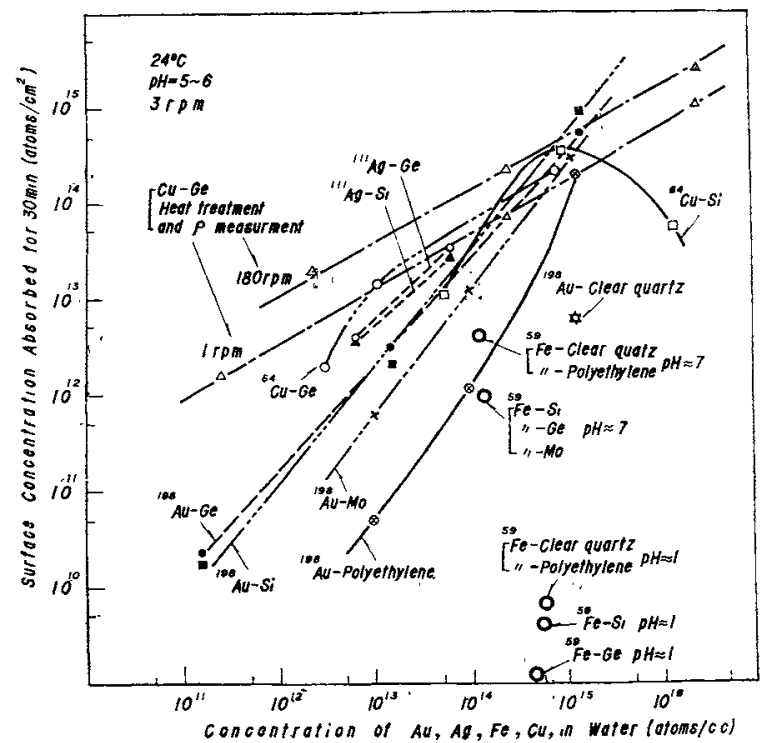

Fig.1 The relations between the surface concentration absorbed from water containing metallic impurities for $30 \mathrm{~min}$, and the concentration of each metallic elements in water. Dot dash lines were obtained from resistivity change caused by heat treatment, assumed that the $\rho$ change was only due to $\mathrm{Cu}$ absorbed on $\mathrm{Ge}$ surface during the dipping for $30 \mathrm{~min}$.

浸漬した場合の $\mathrm{Ge}, \mathrm{Si}$, 透明石英板, Mo 板，ポリエチレ ン板表面の吸着量の関係である。とくに断わりのないもの 
は $\mathrm{pH}=5 \sim 6$ で行なつた実験データーである.龱にはまた 熱処理による比抵抗変化から求めた $\mathrm{Ge}$ 表面に対する $\mathrm{Cu}$ 吸 着量の実験結果も示した (実験方法については後述する)．

Fig.2 は $\mathrm{NaCN} 30 \%$ 水溶液中の $\mathrm{Fe}$ 抽上び $\mathrm{Au}$ 錯イオン

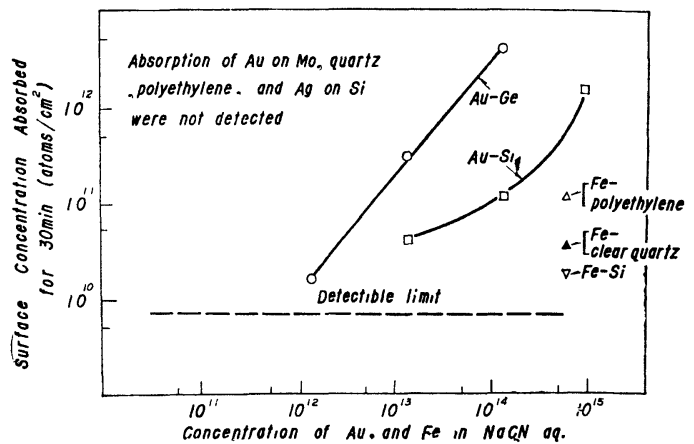

Fig.2 The relation between the surface concentration absorbed from $\mathrm{NaCN} 30 \%$ aq. for 30 $\mathrm{min}$, and the concentration of $\mathrm{Au}$ and $\mathrm{Fe}$ atoms in $\mathrm{NaCN} 30 \%$ aq.

の濃度と, 30 分間の $\mathrm{Ge}, \mathrm{Si}$ 表面吸着量の関係である。石 英, Mo, ポリエチレンでは $\mathrm{NaCN}$ 水溶液中 $\mathrm{Au}$ の吸着は 検知できなかつた。また $\mathrm{NaCN}$ 水溶液中 $\mathrm{Ag}$ ，打よび $\mathrm{Cu}$ は, $\mathrm{Ge}, \mathrm{Si}$, 石英, Mo, およびポリエチレンのいゔれの表 面に対する吸着も検知できなかつた。

Fig.3 は $\mathrm{HF}$ (石英の場合)，または $\mathrm{HF}+\mathrm{HNO}_{3}$ (その他 の場合) 中の $\mathrm{Au}, \mathrm{Ag}$ 濃度と表面吸着量の関係である.な拈 王水中 $\mathrm{Ag}$ (約 $7 \times 1013 / \mathrm{cc}$ ) の $\mathrm{Si}$ 表面に対する吸着は検知出

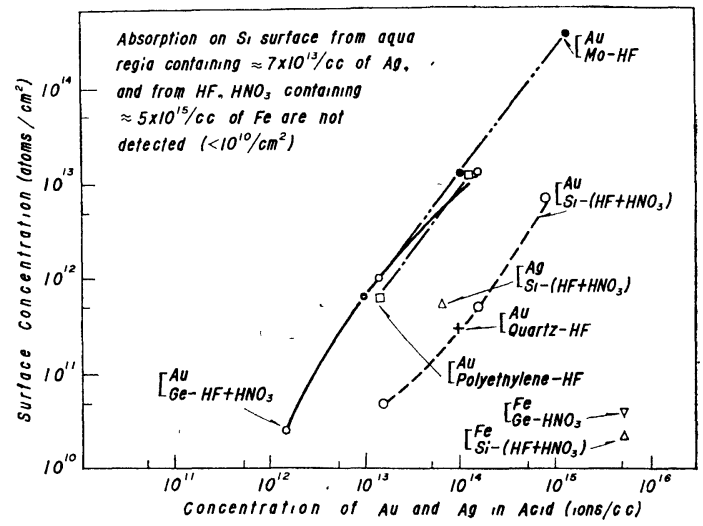

Fig.3 Relation between surface concentration absorbed for $30 \mathrm{~min}$ and concentration of $\mathrm{Au}$ and $\mathrm{Ag}$ in acid.

来なかつたまをた Fe $5 \times 1015 / \mathrm{cc}$ を含む $\mathrm{HNO}_{3}, \mathrm{HF}+\mathrm{HNO}_{3}$ 中浸漬，または酸食による $\mathrm{S}_{1}$ 表面の吸着は検知できなか つた。な执上記の $\mathrm{HF}+\mathrm{HNO}_{3} て ゙ \mathrm{Ge}$ または $\mathrm{Si}$ を酸食した 場合は，褐色の煙を出すまで酸食を行なつたので，その時 間は一定ではない。

また $\mathrm{KCN}$ 粉末を $\mathrm{Cu}$ と同樣に JRR-1 で中性子照射した ものを水にとかし $(1019 / \mathrm{cc})$ た中に $\mathrm{Ge}$ ペレット $\left(150 \mathrm{~cm}^{2}\right.$ の表面積をもつ)を 30 分間浸漬後水洗したが，検出感度 $2 \times 1013 / \mathrm{cm}^{2}$ で吸着量を検知することができなかつた。
つぎに Fig.4 は各種物質表面に吸着された $\mathrm{Cu}, \mathrm{Au}$ が $\mathrm{NaCN} 30 \%$ 水溶液中で脱着してゆく様子を示したもので ある. また Fig.5 は Si 表面の $\mathrm{Au}$ が $\mathrm{HF}+\mathrm{HNO}_{3}(1: 2)$ に よる酸食によつて減少してゆく様子を示したものである。

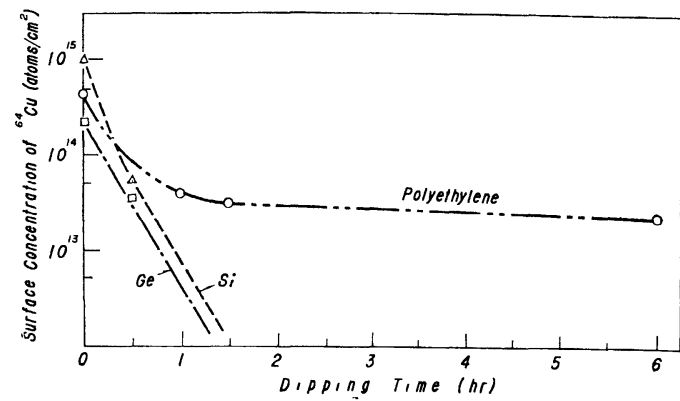

Fig.4(a) Aspect of desorption of absorbed ${ }^{64} \mathrm{Cu}$ on surface of $\mathrm{S} 1, \mathrm{Ge}$ and polyethylene caused by $\mathrm{NaCN} 30 \%$ aq. treatment.

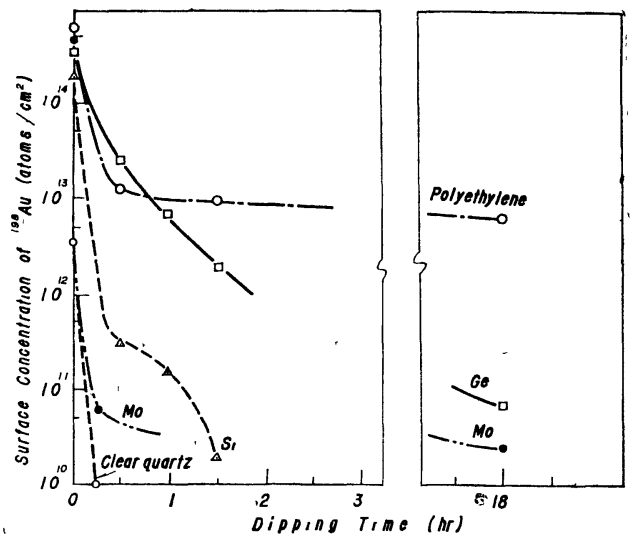

Fig. 4(b) Aspect of desorption of absorbed $198 \mathrm{Au}$ on surface of $\mathrm{Si}, \mathrm{Ge}, \mathrm{Mo}$, clear quartz, and polyethylene caused by $\mathrm{NaCN} 30 \%$ aq. treatment.

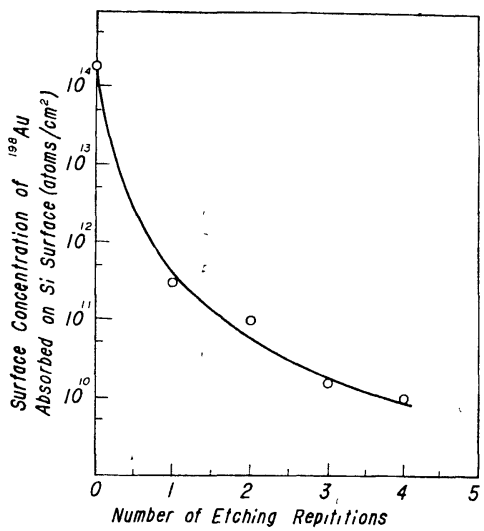

Fig. 5 Aspect of reduction of absorbed $\mathrm{Au}$ on Si surface caused by repeated etching using $\mathrm{HF}+\mathrm{HNO}_{3}(1.2)$.

酸食液およびポ リエチレンビー カーは 1 回ごと に新しいものに とりかえて実験 を行なつた。ま た各種物質に吸 着された $\mathrm{Au}$ ， およびFeは王 水処理によつて 8 Fig. $4(\mathrm{~b})$ と 同程度，または それ以上の速度 で脱着すること も明らかになつ た。

\footnotetext{
*本節の一部は (4)に発表したものである。
} 
Ge の熱処理による電気的性質の変化の原因となる不純 物の大部分は銅であるとされている(1)。そのためにる，よ り精密な実験が望ましいのであるが， $64 \mathrm{Cu}$ 用いる方法は 現在では前述のように感度が低い。ここでは $\mathrm{Ge}$ 中 $\mathrm{Cu} の$ 拡散係数が著しく大きい(6)ことを利用して，熱处理による $\mathrm{Ge}$ の比抵抗変化を用いて $\mathrm{Ge}$ 表面の $\mathrm{Cu}$ 吸着量を測定する ことに成功したのでその結果を記す。

\section{1. 実験方法}

比抵抗 $(\rho)$ ，伝導型(熱起電力による)を測定した $\mathrm{Ge}$ 試片 を $\mathrm{HF}+\mathrm{HNO}_{3}(1: 1)$ で酸食する。用いた試料は主に $\mathrm{Sb}$ を 添加した $\rho$ が $30 \Omega \mathrm{cm}$ でN型の Ge で厚さは約 $4 \mathrm{~mm}$ の薄 片である.つぎに試料を $\mathrm{KCN}$ 水溶液に 5 時間以上浸漬後, 脱イオン水, または脱イオン水をさらに全透明石英製連続 2 回蒸溜装置で蒸溜したもので洗滌し，つぎに種々の濃度 の $\mathrm{Cu}$ イオンを含む水中に浸漬する. その後試片を純水洗 滌乾燥してから，Cuイオン濃度の高い水中に浸清したも のは，Mo管中で*, 純水または $\mathrm{Cu}$ イオン濃度の低い水中 に浸漬したものは通電加熱法**で約 $850^{\circ} \mathrm{C}$ 亿 1 時間保持す る. 冷却後, $\rho$, 伝導型を再測定し, 加熱前後の $\rho$, 伝導型 の変化は $\mathrm{Ge}$ 表面に吸着されていた $\mathrm{Cu}$ が $\mathrm{Ge}$ 内部に均一 に拡散したためであるとして, 加熱前 $\mathrm{Ge}$ 表面に吸着され ていた $\mathrm{Cu}$ の量を求める。それにはまず，Ge 中に固溶した $\mathrm{Cu}$ は禁止帯中に三つのアクセプタ準位を作るとして (7)， $\mathrm{Sb}=4 \times 1013 / \mathrm{cc}$ ( $\mathrm{N}$ 型 $30 \Omega \mathrm{cm}$ に相当する)，拈よび種々の濃 度のCu を固溶する場合の $\rho$, 伝導型と $\mathrm{Cu}$ 濃度の関係をグ ラフにしておく．このグラフと加熱後の $\rho$ から $\mathrm{Ge}$ 中に侵 入した $\mathrm{Cu}$ 濃度を求める。そしてこの值に試料の容積と表 面積の比を乗じて $\mathrm{Ge}$ 表面の $\mathrm{Cu}$ 吸着量を求める. 液の㩭 找の条件はR.I，を用いた実験の場合と同梯である，Cu イ オン吸着後の水洗時間, および $850^{\circ} \mathrm{C}$ の熱処理時間（1時 間と 2 時間) による差は添とんど認められないことはあら かじめ確めた。

\section{2. 実験結果}

吸着速度を支配する因子はかなり多い，著者らは水中の $\mathrm{Cu}$ イオン濃度 $\left[\mathrm{Cu}{ }^{++}\right]_{\mathrm{w}}$, 水の $\mathrm{pH}$, 陰イオン $\left(\mathrm{NO}_{3}{ }^{-}\right.$と $\mathrm{SO}_{4}-$-), 水の温度, 水中の酸素, 水の㩭找, 試料の結晶 面, 此抵抗, 伝導型, 浸清時間などと $\mathrm{Ge}$ 表面吸着 $\mathrm{Cu}$ 濃 度 $[\mathrm{Cu}]_{\mathrm{s}}$ の関孫を求めたが, その全体を統一的なモデルで 説明することはできなかつた。そそれ故，以下には結果の中 で重要と思われるものについてのみ述べる.

Ge の比抵抗, 伝導型, 光の照射, 表面酸食処理の種類 (平滑な面与えるもののみ), 陰イオンの種類には吸着速度 は依存しないらしい。また結晶面は大部分 (111) 面につい

(6) F.C.Frank and D.Turnbull: Phys. Rev., 104 (1956), 617 .

* Mo 管中 $850^{\circ} \mathrm{C} \times 1 \mathrm{hr}$ 加熱炕よる $\mathrm{Cu}$ 侵入量は $\mathrm{Ge}$ 単 位表面積当り $\leqslant 1012 \mathrm{Cu}$ 原子 $/ \mathrm{cm}^{2}$ である(4).

** 内径 $70 \mathrm{~mm}$ の透明石英管中で $3 \times 3 \times 40 \mathrm{~mm}$ の試片 をMo電極にクランプして通電加熱する.

( 7 ) H.H.Woodbury and W.W.Tyler: Phys. Rev., $105(1957), 84$.

て実験を行なつた。少数の (100) 面について得られたデー ターと比較すると，(100) 面の方が若干吸着速度が大きい らしいが,データーのばらつきにかくされて明らかではな い。また水中の酸素含有量が多いほど, 吸着速度は小であ

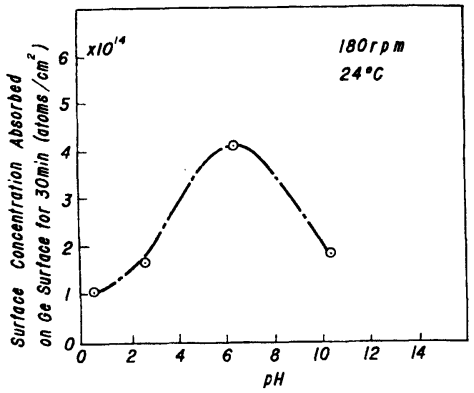
ig.6 Relation between surface con- $2.4 \times 10^{14} / \mathrm{cc} の 24$

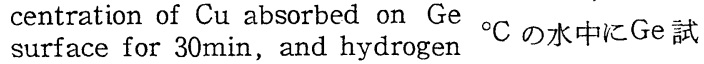
ion concentration of water con- 片を30 分間浸漬 taining $2.4 \times 10^{14}$ ions $/ \mathrm{cc}$ of $\mathrm{Cu}$ ion. した場合の $[\mathrm{Cu}]_{\mathrm{s}}$ と $\mathrm{pH}$ の関係を示す. 以後の実験はすべて $\mathrm{pH}=5 \sim 6$ で行 われたものである。

Fig.1に示されている 2 本の鎖線は $\left[\mathrm{Cu}^{++}\right]_{\mathrm{w}}$ と 30 分間 浸漬の場合の $[\mathrm{Cu}]_{\mathrm{s}}$ の関係を二つの攪找条件について求 めたものである.

Fig.7 は $\left[\mathrm{Cu}^{++}\right]_{\mathrm{w}}=2.4 \times 10^{14} / \mathrm{cc}$ で, 水温を種々に変

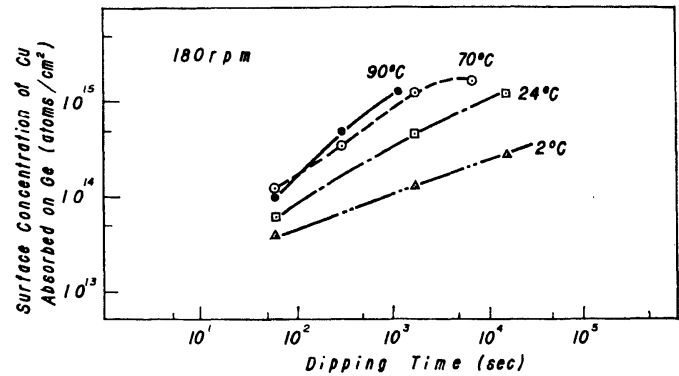

Fig.7 Dipping time dependence of surface concentration of $\mathrm{Cu}$ on $\mathrm{Ge}$ surface absorbed from water containing $2.4 \times 10^{14}$ ions/cc of $\mathrm{Cu}$ ions.

之た場合の $[\mathrm{Cu}]_{\mathrm{s}}$ と浸清時間の関係である。同図上り同 一 $[\mathrm{Cu}]_{\mathrm{s}}$ に拈ける吸着速度を求め $1 / T$ とともにグラフに プロットしてみたが，単一の活性化エネルギーを得ること ができなからた

\section{IV. 考察}

\section{1. 吸着の機 構}

本研究は各材料表面に対する水溶液中不純物の吸着の機 構を明らかにするために行われたものではなく，污染の程 度の推定と, 污染の除去法の確立のためになされたもので ある.それ故吸着の機構を論ずるにはデーターが不完全で ある.ここでは $\mathrm{Ge}$ 表面への $\mathrm{Cu}$ の吸着に 対するやや詳細 な実験結果と, 他のデーターを組合せて若干の考察を行な 3 .

(1) $\mathrm{Ge}, \mathrm{Si}$ 上 $\mathrm{Au}, \mathrm{Ag}, \mathrm{Cu}$ 
水溶液から $\mathrm{Ge}, \mathrm{Si}$ 表面に吸着された $\mathrm{Au}, \mathrm{Ag}, \mathrm{Cu}$ が水洗 でほとんど脱着しないことは, 機構が物理吸着ではないこ とを示している. Fig.7 の実験結果より活性化ェネルギー を得ることができなかつたこと，および Fig.7の $[\mathrm{Cu}]_{\mathrm{s}}$ と 封間の関係が Elovichの関係式を満足しないことは， Ge 表面に対する $\mathrm{Cu}$ の吸着の機構の複雑であることを示して いる．また水中酸素含有量により $[\mathrm{Cu}]_{\mathrm{s}}$ が異なることは， $\mathrm{Ge}$ の溶解速度*が吸着速度に影響をおよぼしている可能性 があることを示している. なた $\mathrm{pH}$ と $[\mathrm{Cu}]_{\mathrm{s}}$ の関係より [H+]が吸着に利いていることがわかるが，このことも温 度依存性を複雑にしている一因となる可能性がある。

$\mathrm{Ge}, \mathrm{Si}$ に対する $\mathrm{Ag}$ の挙動は $\mathrm{Cu}$ に近いと考えられる が， $\mathrm{Au}$ は $\mathrm{NaCN}$ 水溶液からも吸着される点が異なる.

\section{(2) $\mathrm{Ge}, \mathrm{Si}$ 上 $\mathrm{Fe}$}

$\mathrm{Ge}, \mathrm{Si}$ 表面への $\mathrm{Fe}$ の吸着に 対する $\mathrm{pH}$ の影響は非常に 大きい. $\mathrm{pH}=5$ では水中の $\mathrm{Fe}(\mathrm{OH})_{3}$ の溶解積より $\mathrm{Fe}^{+++}$ の溶解度は $2 \times 1010 / \mathrm{cc}$ 程度となり, 本実験条件の水中 $\mathrm{Fe}$ の大部分は $\mathrm{Fe}(\mathrm{OH})_{3}$ のコロイドとして存在していること になる.すなわち $\mathrm{pH} \approx 7$ で $\mathrm{Fe}$ の吸着量が急増している のはコロイド状 $\mathrm{Fe}(\mathrm{OH})_{3}$ の吸着によるものと考えられる.

\section{(3) その他}

石英, Mo,ポリエチレン表面に吸着されたものも水洗で 簡単にはとれない,とくにポリェチレンに吸着したものは， Fig.4からもわかるよ 万に非常に脱着し難い。これらはい ずれも吸着の機構が化学吸着であることを示していると思 われるが，より精密に論ずるにはデーターが不足である.

$\mathrm{Ge}$ 上 $\mathrm{Cu}$ の吸着のデーターは ${ }^{64} \mathrm{Cu}$ によるのと, 熱処 理による比抵抗変化から求めたものとが比較的よく一致し ている、 $\left[\mathrm{Cu}^{++}\right]_{\mathrm{w}}$ の小である範囲で, 両者の值がくい違 つているのは, この範囲の ${ }^{64} \mathrm{Cu}$ による実験結果は, 前述 したように大量のペレットを用いたため, ペレット同志が 重なり合つて有効表面積が減少したためと考えられる.

\section{2. 表面清浄化の最適条件}

加工した $\mathrm{Ge}, \mathrm{Si}$ 試料表面には大量の不純物が付着して いると考えられる．そして通常これを取除くには，HF+ $\mathrm{HNO}_{3}$ 溶液て酸食後, 純水で洗滌を行なう.本節で流以下 に表面の清浄化に関して酸食, 水洗の最適条件について考 察を行なう.

Fig. 3 より王水中 $\mathrm{Ag}+$ は $\mathrm{Si}$ 表面に吸着されないが， $\mathrm{HF}+\mathrm{HNO}_{3}$ で酸食した場合には，Au $\mathrm{Ag}$ も Ge, Si 表 面に吸着することがわかる. また Fig.2 より $\mathrm{NaCN}$ 中の $\mathrm{Au}$ や $\mathrm{Fe}$ も $\mathrm{Si}, \mathrm{Ge}$ 表面に吸着する. そしてこれらの事実 は常に Fig. 4 扎よび 5 などの脱着の実験結果と考え合せ ることが必要である.すなわちFig.4 执よび 5 で測定して いるのは吸着放射能の減少の程度であつて, 実際に $\mathrm{NaCN}$ 水溶液洗滌，または酸食をくり返して表面の清浄化を図る 場合には, 最終的な表面の污染の程度はFig.2または 3 の

* W.W.Harvey and H.C.Gatos: J.Electrochem. Soc., 105 (1958)，654 に上ると水中酸素濃度が增大 すると $\mathrm{Ge}$ の水による溶解速度わ增加する。
関係で決定されるのである，とれ故表面清泱化に当つて は, 当然のことながら, 使用する薬品の純度が問題とな る.そして污染を極小にする目的では JIS 特級程度の純度 では不充分である。しかし $\mathrm{HF}, \mathrm{KCN}$ などはそれ以上の精 製が容易ではない，試薬の精製の容易さから考えると，蒸 溜によつて精製することが可能な $\mathrm{HCl}, \mathrm{HNO}_{3}$ の使用が好 ましい，筆者らの用いた全透明石英製 1 回蒸溜装置では $59 \mathrm{Fe}$ を加えた $\mathrm{HCl}$ および $\mathrm{HNO}_{3}$ を蒸溜すると，溜分は $59 \mathrm{Fe}$ が約 $1 / 5000$ に低下することを確めた。また通常使用 している脱イオン水はコロイド状不純物（とくに Fe) が含 まれている可能性が大である，そして Fig.1より明らかな ようにコロイド状 $\mathrm{Fe}$ はとくに吸着され易い。このコロイ ド状 Fe を除去するため我々は全透明石英製連続 2 回蒸溜 装置を用いた，Ge,Si 試料表面の金属不純物による污染を 極小にするには,試料を酸食後,上記のよ5に蒸溜した $\mathrm{HCl}$ および $\mathrm{HNO}_{3}$ を用いて作つた王水中に数時間浸漬し，その 後上記の脱イオン水を 2 回蒸溜した純水で注意深く洗滌す るのが好ましいであろう。またこのとき用いられるポリェ チレン容器にも充分留意しなければならないことは明らか である.Fig.4より明らかなようにポリエチレンに吸着さ れた不純物はきわめて脱着しにくく，後に徐々に水中に不 純物を放出する. 新しいポリエチレン容器は使用前に上記 蒸溜王水で充分長時間洗滌すべきであり，また一旦強い污 染をうけたポリエチレン容器を用いるのは好ましくない. そして污染されている試料を酸食する場合に用いる容器 と, 王水処理に用いると容器とは区別して用いるのが好ま しいこともわかる. 王水処理, 执よび水洗の場合はむしろ 透明石英製ビーカーの方が好ましいと思われる。

筆者らは上記のように充分留意して表面処理を行なつ た $100 \mu \sec$ の小数キャリアの寿命をるつ浮遊帯熔融法 によつて製造されたSi 単結晶を水冷石英容器中で高周波 により直接約 $1200^{\circ} \mathrm{C} に 1$ 時間加熱後急冷したが， 寿命は 常に $60 \mu \mathrm{sec}$ 以上を示した．この值は上記試料を酸食後脱 イオン水洗滌して同様な熱処理を加えた場合に得られる $\leqslant 20 \mu \sec$ の寿命と此較して, 相当表面が清浄化されてい ることを示していると思われる。

\section{V. 総 括}

（1）各種水溶液で処理した場合の $\mathrm{Ge}, \mathrm{Si}$, 石英, Mo, ポ リエチレン表面の污染の程度を放射性同位元素の使用, お よび加熱による Ge の比抵抗変化の测定によつて検討し た。

（2）水中に含まれる $1013 / \mathrm{cc}(<0.01 \mathrm{ppm})$ の濃度の $\mathrm{Au}$ ， $\mathrm{Ag}, \mathrm{Cu}$ の各イオンは $\mathrm{Ge}, \mathrm{Si}$ 表面に 30 分後 $1012 / \mathrm{cm}^{2}$ 以上 の表面濃度に吸着される。

(3) 水中の $\mathrm{Fe}$ は $\mathrm{pH}=1$ ではほとんど吸着されないが, $\mathrm{pH} \approx 7$ では非常に吸着され易くなる。これは $\mathrm{Fe}(\mathrm{OH})_{3}$ の コロイド状物質で吸着されることを示していると思われ る。 
(4) $\mathrm{HF}+\mathrm{HNO}_{3}$ 中 $\mathrm{Au}, \mathrm{Ag}, \mathrm{NaCN}$ 水容液中 $\mathrm{Au}, \mathrm{Fe}$ 江 $\mathrm{Ge}, \mathrm{Si}$ 表面炕吸着される。このこと, 阽よび純水中不純物 の吸着が，酸食， $\mathrm{NaCN}$ 水溶液浸清後水洗した $\mathrm{Ge}, \mathrm{Si}$ 試 料の表面清净化の限界を決定する。

（5）Ge 招よび Si試料表面清净化の好適条仵について考
察を行なつた。

終り以本研究逢行に当り種及监指導，御援助を頂いた東 芝中央研究所 多田格三主任研究員, 藤井 勲氏, 管球事業 部半導体技術部の加藤 宏課長, 招よび実験を担当された 根本 忠氏，および三輸政博氏に深謝します。 